Pre-print of conference paper for the European Conference on Information Literacy 2016 (Prague, October 9-13, 2016) to be published in "Information Literacy: Key to an Inclusive Society," Communications in Computer and Information Science [forthcoming], (c) Springer International Publishing AG.

\title{
Assessing Awareness of Library Services: An Ethnographic Examination of Bachelor Students at Two Czech Technology Universities
}

\author{
Alena Chodounská', Stephanie Krueger ${ }^{1}$ \\ 'Czech National Library of Technology, Prague, Czech Republic \\ \{alena.chodounska, stephanie.krueger\} @techlib.cz
}

\begin{abstract}
In this paper, the authors present interim research results from an ongoing ethnographic examination of eight engineering undergraduate students from two technology universities in Prague, Czech Republic. A multi-layered data gathering strategy was employed, including semi-structured in-person interviews as well as in situ and virtual observations of participants interacting with learning environments. This data enabled the authors to examine whether or not students are aware of library services. "Library services" are here broadly defined to include not only traditional support services but also new, emerging areas of activity which can be categorized under the broader concept of undergraduate student support [1]. Findings indicate very poor awareness of library offerings although participants were aware of the library as a study space. The authors additionally touch briefly upon the concept of "backward design" [2] for service development, in which research data is gathered and considered prior to service design and launch.
\end{abstract}

Keywords: Ethnography, engineering undergraduates, student-centered information literacy, backward instructional design.

\section{Introduction}

At the Czech National Library of Technology (NTK), because of many twists and turns of history which extend beyond the scope of this paper [3], we are in the unique position of being able to redesign all of our academic support services, both physical and virtual.

What this means in practical terms is that the NTK academic services team has set as a purposeful internal goal the use of data about our patrons and potential future patrons before we create, launch, or reconsider any service offering, including information literacy initiatives. In addition to traditionally-generated library utilization metrics, we are keenly interested in gathering contextual data using ethnographic strategies - including emerging forms of virtual observation-because such data provide emic depth and richness to our understanding of patrons and their needs.

In this introductory section, the authors conduct a brief literature review and discuss the origins of this research project. Section 2 formally presents the research questions and describes research methods and design. Section 3 is devoted to a 
Pre-print of conference paper for the European Conference on Information Literacy 2016 (Prague, October 9-13, 2016) to be published in "Information Literacy: Key to an Inclusive Society," Communications in Computer and Information Science [forthcoming], (c) Springer International Publishing AG.

description of data gathered during the project. Section 4 provides data analysis in relation to our research questions (very brief, because of space limitations) followed by the conclusion in Section 5.

\subsection{Literature Review}

Research studies which consider the perhaps unique educational service needs of Millennial generation engineering undergraduates are quite rare and are often, as outlined importantly by [4], focused on how students interact with the online environment and technological devices rather than on library offerings. Library-focused studies such as [5] and [6] are already several years old. A full review of literature specifically about information literacy in engineering technologies is provided by [7] with the conclusion across the literature that "'one shot' instruction does not work" [p. 163]. [8] and [9] describe the needs of international students studying in Englishlanguage engineering environments, an area of special interest to the authors because several participants in this study must work with materials in English and not in Czech, their native language.

Ethnographic strategies have been increasingly used in recent years to examine library environments; see a survey of such studies across many disciplinary areas at [10]. Additionally useful descriptions of ethnographic research techniques appear in [11], [12], [13], [14]; [15] provides a critical discussion of the application of anthropological methods to library and information science research.

This study is the second of its kind, following methodological considerations laid out in [16], to include elements of virtual ethnography in the form of screenshots taken by research participants in order to capture moments of time in which they interact with information online. In the future, the authors would be like to additionally use video screen captures and/or mobile video; an interesting non-library example of the latter is provided by [17].

\subsection{Origins of Research}

The original research the authors describe here is part of a broader, ongoing study being conducted by one of the paper's authors about the research and study patterns of engineering undergraduates at the University of Chemistry and Technology, Prague (UCT Prague) and the Czech Technical University in Prague (CTU), two institutions which physically surround our library. Because of space limitations for this paper, the authors provide only an interim set of results and brief discussion of their potential applicability to service offerings at NTK.

The description of the in-process project provides a model for others interested in transcending the boundaries of traditional quantitative research approaches at their institutions. Micro-level studies such as this one can enrich the small corpus of literature about Millennial engineering undergraduates and, importantly, inspire future analyses about the needs of the post-Millennial students. 
Pre-print of conference paper for the European Conference on Information Literacy 2016 (Prague, October 9-13, 2016) to be published in "Information Literacy: Key to an Inclusive Society," Communications in Computer and Information Science [forthcoming], (c) Springer International Publishing AG.

\section{Methods}

In this section, the authors define research questions and describe methodology and design of the research project.

\subsection{Research Questions}

The first research question (RQ1) considered in this paper is: How are selected undergraduate engineering students at two technology universities in Prague interacting with libraries (if at all)? We also ask (RQ2): Do these students feel libraries can play a role in their overall educational process? Finally, the authors discuss (RQ3) how instructional/information literacy support services might be potentially developed in relation to interim research findings.

\subsection{Research Methodology}

Ethnographic strategies were employed as part of the broader in-process study. The authors' goals beyond providing insight into the aforementioned research questions for this paper: an examination of the lifeworlds of eight undergraduates, both in-person and online, as a starting point for enhancing our understanding of their learning processes and possible support needs as well as to identify areas for future research (both quantitative and qualitative) over additional populations.

The following section describes specific aspects of how ethnographic techniques were employed in this study, including types of data gathered during the research process, recruitment of participants, and ethical considerations.

\subsection{Research Design}

\section{Gathering Data}

Ethnographic research can generate a rich amount of data over time to be analyzed and considered. This, the authors feel, is advantageous - but it does mean researchers interested in conducting such a project must be prepared to devote a serious investment of time into data gathering and analysis.

Because we were interested learning about both the in-person and virtual lifeworlds of our research participants, data was gathered in both realms of social interaction, as seen in Tables 1 and 2. The semi-structured interview protocol was modeled loosely on that described in [6, pp. 7-15]. 
Pre-print of conference paper for the European Conference on Information Literacy 2016 (Prague, October 9-13, 2016) to be published in "Information Literacy: Key to an Inclusive Society," Communications in Computer and Information Science [forthcoming], (c) Springer International Publishing AG.

Table 1. Data gathered/to be gathered in-person (fieldwork).

\begin{tabular}{lll}
\hline Mechanism & Purpose & Data Type \\
\hline $\begin{array}{l}\text { Semi-structured } \\
\text { interviews }\end{array}$ & $\begin{array}{l}\text { To ask specific questions related to research } \\
\text { project; length of each interview varied: 39 to }\end{array}$ & $\begin{array}{l}\text { Mobile phone } \\
\text { recordings, transcribed } \\
\text { to text documents }\end{array}$ \\
$\begin{array}{l}\text { In-person } \\
\text { observation of } \\
\text { campus activities }\end{array}$ & $\begin{array}{l}\text { To supplement interview information; } \\
\text { included visits to open houses but not classes }\end{array}$ & Fieldwork notes, text \\
\hline
\end{tabular}

Table 2. Data gathered/to be gathered virtually (online fieldwork).

\begin{tabular}{|c|c|c|}
\hline Mechanism & Purpose & Data Type \\
\hline $\begin{array}{l}\text { Online information } \\
\text { about participant } \\
\text { schools }\end{array}$ & $\begin{array}{l}\text { To learn more about participant study } \\
\text { programs and learning environments }\end{array}$ & $\begin{array}{l}\text { Notes about findings, } \\
\text { text }\end{array}$ \\
\hline $\begin{array}{l}\text { Resources } \\
\text { mentioned in } \\
\text { interviews }\end{array}$ & $\begin{array}{l}\text { To understand tools used commonly by } \\
\text { participants in their study }\end{array}$ & $\begin{array}{l}\text { Notes about findings, } \\
\text { text }\end{array}$ \\
\hline $\begin{array}{l}\text { Screenshots taken } \\
\text { by participants }\end{array}$ & $\begin{array}{l}\text { To observe virtual information interactions of } \\
\text { research participants. Task: Over } 14 \text { days, } \\
\text { take screenshots of information-related activ- } \\
\text { ities you feel would be illustrative of your } \\
\text { studies and learning online }\end{array}$ & $\begin{array}{l}\text { Image files stored to } \\
\text { Google Drive, by } \\
\text { participant }\end{array}$ \\
\hline $\begin{array}{l}\text { NTK web, social, } \\
\text { and resource } \\
\text { statistics }\end{array}$ & $\begin{array}{l}\text { To analyze behavior of students using these } \\
\text { resources and compare to interview data }\end{array}$ & $\begin{array}{l}\text { Text and numerical } \\
\text { data }\end{array}$ \\
\hline $\begin{array}{l}\text { Photos taken by } \\
\text { participants } \\
\text { ("photo diary") }\end{array}$ & $\begin{array}{l}\text { To illustrate research participant lifeworlds. } \\
\text { Task: Take pictures of anything you feel rep- } \\
\text { resents your life as a student. }\end{array}$ & Image files \\
\hline
\end{tabular}

\section{Recruitment of Research Participants}

The paper's first author recruited eight students for this project in order to provide a manageable set of data with which to work because of an autumn 2016 deadline. This population $(n=8)$ is not representative nor random in the statistical sense; this is not necessary in such a qualitative ethnographic study as long as findings are not generalized beyond the specific purposes of this paper and the larger research project. [2, pp. 10-11] provides interested readers with a useful discussion of how to consider ethnographic generalization as opposed to "abstract" survey approaches.

In recruiting participants, the paper's first author contacted several professors at CTU and UCT Prague and also used NTK's Facebook channel. In the end, all participants were recruited via modified snowball sampling (see definition in [18, p. 49] and commentary in [19]): three friends of the paper's first author suggested potential participants who, in turn, recruited additional participants. Because of this, students from only four schools ("faculties") are included here. Future studies should include all campus schools in order to be fully representative of the environment.

One participant has begun Master-level studies and here was asked to comment exclusively on his undergraduate experience. Table 3 below provides an overview of 
Pre-print of conference paper for the European Conference on Information Literacy 2016 (Prague, October 9-13, 2016) to be published in "Information Literacy: Key to an Inclusive Society," Communications in Computer and Information Science [forthcoming], (c) Springer International Publishing AG.

project participants, including their "year" of bachelor studies. All participants were born in 1990 or later.

Table 3. Project participants ( $\mathrm{n}=8$; five females and three males).

\begin{tabular}{lll}
\hline Participant/Gender & University/Field of Study & Year of Study \\
\hline 1/female & CTU/Information Technology & 1 \\
2/female & CTU/Civil Engineering & 4 \\
3/female & UCT Prague/Food and Biochem. Technology & 3 \\
4/female & UCT Prague/Food and Biochem. Technology & 3 \\
5/female & UCT Prague/Food and Biochem. Technology & 3 \\
6/male & CTU/Civil Engineering & 3 \\
$7 /$ male & CTU/Information Technology & BSc. completed/MSc. \\
& & 1 \\
$8 /$ male & CTU/Information Technology & $2-3$ \\
\hline
\end{tabular}

\section{Ethics and Privacy}

The American Anthropological Association's Statement of Ethics: Principles of Professional Responsibilities [17] were used to guide this study because neither NTK nor the Division of Information and Library Studies (KISK) of the Faculty of Arts at Masaryk University in Brno, Czech Republic (the larger study sponsor) have an institutional review board. All personal information has been removed for discussion of participants, who have been made aware of the purposes of this research as well as possible publication outputs and are able to cease participation at any time.

\section{Results to Date}

This section provides an overview of data gathered in the project to date.

\subsection{Data Description}

As of the date of submission of this paper, all in-person and virtual fieldwork has been completed; some transcription and coding is still in progress.

\section{Semi-Structured Interviews}

Eight semi-structured interviews were conducted in the Czech language. These interviews were recorded on mobile phones and are in the process of being transcribed and coded for analysis. Because of space limitations, the interview protocol is not included here, but authors will provide it upon request. 
Pre-print of conference paper for the European Conference on Information Literacy 2016 (Prague, October 9-13, 2016) to be published in "Information Literacy: Key to an Inclusive Society," Communications in Computer and Information Science [forthcoming], (c) Springer International Publishing AG.

Table 4. Semi-Structured Interview Data.

\begin{tabular}{lll}
\hline Participant/Gender & Date of Interview & $\begin{array}{l}\text { Interview Duration } \\
\text { (Minutes) }\end{array}$ \\
\hline 1/female & 9.3 .2016 & 39 \\
2/female & 9.3 .2016 & 61 \\
3/female & 16.3 .2016 & 141 \\
4/female & 6.4 .2016 & (still being transcribed) \\
5/female & 6.4 .2016 & (still being transcribed) \\
6/male & 6.4 .2016 & 41 \\
7/male & 20.4 .2016 & 43 \\
8/male & 24.5 .2016 & 68 \\
& & Average length (of 6 \\
& & transcribed): 66 \\
\hline
\end{tabular}

\section{Screenshot Data}

Research participants provided 141 screenshots illustrating their own interpretations of "use of information for their studies" over the course of two weeks. This task which was purposefully broad to let students define both "information" and "use" from their own perspectives.

Table 5. Screenshot Data.

\begin{tabular}{lll}
\hline Participant/Gender & Date Screenshots Provided & $\begin{array}{l}\text { Number of } \\
\text { Screenshots }\end{array}$ \\
& & 30 \\
1/female & 29.5 .2016 & 14 \\
2/female & 24.5 .2016 & 27 \\
3/female & 19.5 .2016 & 3 \\
4/female & 16.5 .2016 & 5 \\
5/female & 28.5 .2016 & 7 \\
6/male & 29.5 .2016 & 47 \\
7/male & 20.5 .2016 & 8 \\
8/male & 26.6 .2016 & Total screenshots \\
& & provided to date: 141 \\
\hline
\end{tabular}

\section{Photo Diary Data}

To date, six participants have provided 80 photo diary images documenting various aspects of student life from their points-of-view.

Table 6. Photo Diary Data.

\begin{tabular}{lll}
\hline Participant/Gender & Date Photos Provided & Number of Photos \\
\hline 1/female & 26.6 .2016 & 13 \\
2/female & 22.7 .2016 & 15 \\
3/female & 8.6 .2016 & 15 \\
6/male & 25.6 .2016 & 13 \\
7/male & 20.6 .2016 & 10 \\
8/male & 26.6 .2016 & 14 \\
& & Total photos provided \\
& & to date: 80 \\
\hline
\end{tabular}


Pre-print of conference paper for the European Conference on Information Literacy 2016 (Prague, October 9-13, 2016) to be published in "Information Literacy: Key to an Inclusive Society," Communications in Computer and Information Science [forthcoming], (c) Springer International Publishing AG.

\section{$4 \quad$ Data Analysis and Discussion}

\subsection{RQ1: Interaction with the Library}

How are these undergraduates interacting with the library? Data analyzed to date both reveal a low level of interaction with the library online, with awareness of the library for these students limited to the physical place to study and not as a complementary partner in their studies for exploring potential research resources or learning about specialized software or tools.

One participant, for example, when asked if they would consider asking a librarian for help with their Bachelor thesis, responded: "Maybe as a last resort. I do not want to bother anyone. What's on the Internet is best." Even when the library's individual consultancy services were then explained to this student, they stated they would "probably not" use them - they would go first to their professors and peers (typically over social media outlets, including closed/private groups) as well as online discussion forums (those provided by schools or, for information technology students, specialized forums like Stack Overflow), video tutorials (YouTube), and documentation (for example, Linux man pages). One student noted they would ask their parents for assistance prior to reaching out to anyone else.

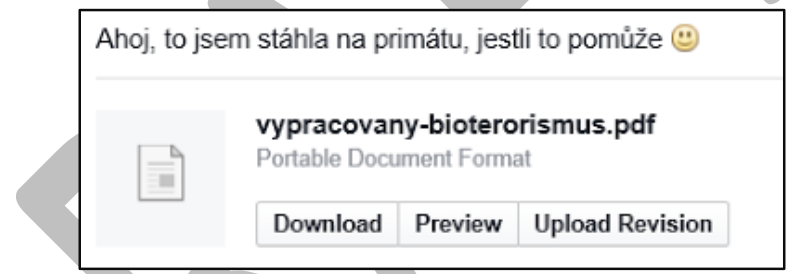

Fig. 1. Sample Facebook secret group commentary (Source: Screenshot data; cropped for privacy reasons)

Remark 1. This figure illustrates peer assistance, with a student sharing a document for peers via a secret Facebook group: Greetings, I downloaded this from the student information portal, Primat, if it helps. Primat.cz is a commercial portal which includes skripta, study booklets written by professors for students, often used in this context textbooks and other materials.

Only one student in this study illustrated use, according to screenshot data, of a library website and/or database (including one advanced search); all other participants exhibited simple keyword searching via Google with a mixture of searches in Czech and English, depending on the topic of interest to them. All Google queries were plain keyword searches with no quotation marks or Boolean operators used (for example, jak psát abstract, or: how do I write an abstract?). One student noted they were unaware of Google Scholar. 
Pre-print of conference paper for the European Conference on Information Literacy 2016 (Prague, October 9-13, 2016) to be published in "Information Literacy: Key to an Inclusive Society," Communications in Computer and Information Science [forthcoming], (c) Springer International Publishing AG.

\begin{tabular}{|lll|ll|l|l|}
\hline Vsechna pole & $\nabla$ & gas chromatography-mass spectrometry & AND \\
\hline Autor & $\nabla$ & & & $\times$ & AND \\
\hline
\end{tabular}

Fig. 2. Sole example of an "advanced" search, NTK discovery tool (Source: Screenshot data)

Remark 2. In this search, the student used a query for gas chromatography-mass spectrometry together the last name of an author (name blackened for privacy), which yielded over eighty results because the student did not limit their search to full text.

Students noted they visit the physical library when they are waiting for classes and/or to meet their peers, because it is centrally-located. No students here consider the library to be a place to browse physical books or journals serendipitously. CTU students, who are not currently registered automatically with the library, do not feel it necessary to be "officially" registered because they can enter the building and use eduroam [20] for connecting to the Internet without registering.

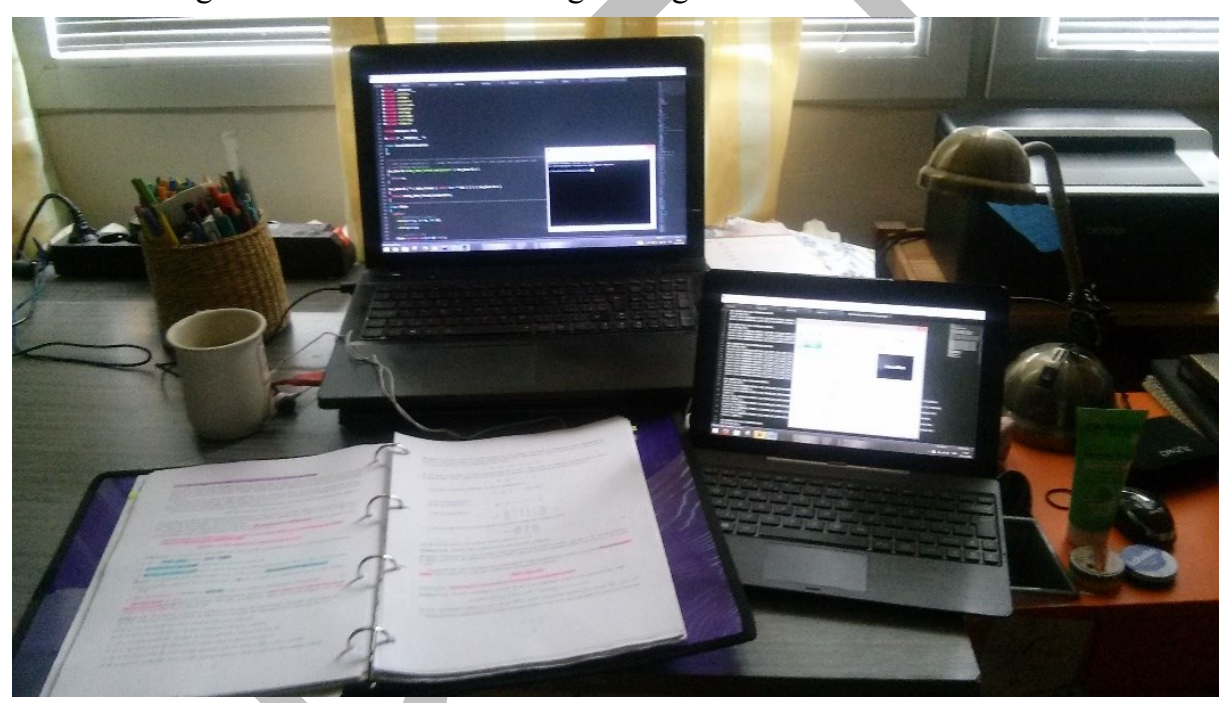

Fig.3. Student study materials at home (Source: Photo diary data)

Several students commented that "all the good books are checked out"instead of reserving materials or using e-Books, they then use study materials provided by their professors or schools or materials posted for shared use to downloading sites like uloz.to.

Students in this study did not know where they might find sample Bachelor theses for review; one student noted that their school does not publish undergraduate theses because of an unwillingness to publish proprietary software code. No student had any awareness that databases such as ProQuest or institutional repositories at other universities (within or beyond the Czech Republic) which might provide examples for them to use. 
Pre-print of conference paper for the European Conference on Information Literacy 2016 (Prague, October 9-13, 2016) to be published in "Information Literacy: Key to an Inclusive Society," Communications in Computer and Information Science [forthcoming], (c) Springer International Publishing AG.

\subsection{RQ2: Perceived Role for Library in Educational Process}

Do these students feel libraries can play a role in their overall educational process? The resounding answer, for interview data analyzed to date, is no. For the students participating in this study, passing exams - both those offered by their schools and those provided by commercial entities offering specialized certification like Cisco Certification Exams [21] — was their primary focus, followed by completion of their Bachelor theses. The one student who had already completed his Bachelor thesis conveyed how difficult the process was for him, particularly selecting and narrowing down his topic and writing mechanics (spelling and proofreading). Such findings for RQ2 raises many interesting questions in terms of the promotion and development of existing support services.

\subsection{RQ3: Applying Findings to Service/Instruction Development}

How instructional/information literacy support services might be potentially developed in relation to interim research findings (applied) library services? To answer in a nutshell: very carefully, because our already-existing promotional system is not working, despite NTK's prominent campus location and marketing efforts over various in-person, web, and social channels. Offering new courses before raising awareness of current services would be putting the cart before the horse and would not address larger issues clearly highlighted by this study: lack of integration of library offerings with course syllabi and lack of promotional activity at the point of need such as links to library content in online student discussion forums.

We must clearly address these issues in parallel to step-by-step mapping of each Association for College and Research Library (ACRL) Information Literacy Standard for Science and Engineering/Technology [22] to an appropriate, aggressive strategic response. These standards will serve as learning outcomes from which we will systematically create methodologies following curricular "backward design" as described by [23, pp. 20-28]. This process must be accompanied by the development of deeper relationships with campus partners regarding undergraduate services as described by [1]. The response must not only include in-person instructional service development but also highly creative interventions into the virtual space already inhabited by students.

\section{Conclusion}

In this brief paper, the authors have shown that research participants are largely unaware of NTK's undergraduate support services and information literacy concepts such as advanced query building. Deeper building of campus partnerships as in [1] as well as meeting students virtually at their point of need will be crucial in the future to addressing issues identified here. The study's findings cannot be generalized over all CTU and UCT Prague undergraduates because the population considered was small, but the authors will conduct additional investigations to expand their analysis. 
Pre-print of conference paper for the European Conference on Information Literacy 2016 (Prague, October 9-13, 2016) to be published in "Information Literacy: Key to an Inclusive Society," Communications in Computer and Information Science [forthcoming], (c) Springer International Publishing AG.

\section{References}

1. Seal, R.,: Resource Sharing Begins at Home: Opportunities for Library Partnerships on a University Campus. Presented at: 14th Interlending and Document Supply Conference, Istanbul, Turkey. Loyola eCommons, Chicago (2015)

http://ecommons.luc.edu/cgi/viewcontent.cgi?article=1036\&context=lib facpubs

2. Dourish, P.: Reading and Interpreting Ethnography. In: Olson, J.S., Kellogg, W.A. (eds.)

Ways of Knowing HCI. pp. 1-18. New York: Springer Science+Business Media (2014).

3. About NTK - Czech National Library of Technology History,

https://www.techlib.cz/en/2749-about-ntk\#tab history

4. Jorhi, A., Teo, H.J., Lo, J., Dufour, M., Schram, M.: Millennial Engineers: Digital Media and Information Ecology of Engineering Students. Computers in Human Behavior, 33, 510 523 (2014), doi:10.1016/j.chb.2013.01.048

5. Gabridge, T., Gaskell, M., Stout, A.: Information Seeking through Students' Eyes: The MIT Photo Diary Study. College and Research Libraries, 69, 510-522 (2008).

http://crl.acrl.org/content/69/6/510.full.pdf

6. Foster, N.F., Gibbons, S. (eds.): Studying Students: The Undergraduate Research Project at the University of Rochester. Chicago: Association of College and Research Libraries. http://www.ala.org/acrl/sites/ala.org.acrl/files/content /publications/booksanddigitalresources/digital/FosterGibbons cmpd.pdf

7. Hill, K.H., Best, M.M., Dalessio, A.P.: Information Literacy in the Engineering Technologies at the Community College: A Literature Review. Community \& Junior College Libraries, 18, 3-4, 151-167 (2012), doi : $10.1080 / 02763915.2012 .812920$

8. Zhao, J. C., Mawhinney, T.: Identifying Challenges Faced by Chinese Undergraduate Engineerng Students in Acquiring Information Literacy Skills - A Report on Survey Findings. Presented at: 2014 ASEE Annual Conference, Indianapolis, IN (2014), https: / / peer.asee.org/20578

9. Zhao, J. C. , Mawhinney, T.: Comparison of Native Chinese-speaking and Native English-speaking Engineering Students' Information Literacy Challenges. The Journal of Academic Librarianship, 41, 6, 712-724 (2014). doi:10.1016/j.acalib.2015.09.010

10. Khoo, M., Rozaklis, L., Hall, C.: A Survey of the Use of Ethnographic Methods in the Study of Libraries and Library Users. Library \& Information Science Research, 34, 82-91 (2012). doi:10.1016/j.lisr.2011.07.010

11. Seadle, M.: Research Rules for Library Ethnography. Library Hi Tech, 29, 3, 409-411 (2011). doi:10.1108/07378831111174378

12. Seadle, M.: Project Ethnography: An Anthropological Approach to Assessing Digital Library Services. Library Trends, 49, 2, 370-385 (2000).

https://www.ideals.illinois.edu/bitstream/handle/2142/8342/

librarytrendsv $49 i 2$ opt. pdf? sequence=3\#page $=157$

13. Emary, L.R.: Librarians are Already in the Field: How and Why to Begin Ethnographic Fieldwork. BIBLIOTHEK-Forschung und Praxis, 30, 2, 138-142 (2015). doi:10.1515/bfp-2015-0016

14. Goodman, V. D.: Applying Ethnographic Research Methods in Library and Information Settings, Libri, 61, 1-11 (2011). doi:10.1515/libr. 2011.00

15. Sandstrom, A.R., Sandstrom, P.E.: The Use and Misuse of Anthropological Methods in Library and Information Science Research, The Library Quarterly: Information, Community, Policy, 65, 2, 161-199 (1995). http://www.jstor.org/stable/4309020

16. Krueger, S.: Beyond the Paywall: A Multi-Sited Ethnographic Examination of the Information-Related Behaviors of Six Scientists (2016). Forthcoming PhD Dissertation, Humboldt-Universität zu Berlin.

17. Spinney, J.: A Chance to Catch a Breath: Using Mobile Video Ethnography in Cycling Research. Mobilities, 6, 2, 161-182 (2011). doi : 10.1080/17450101.2011.552771

18. Walsh, J.: The Highlight Reel and the Real Me: How Adolescents Construct the Facebook Fable. PhD Dissertation (2014). Boston: Boston University. http://gradworks.umi.com/36/45/3645870.html

19. Goodman, L.A.: Comment: On Respondent-Driven Samplıng and Snowball Samplıng in Hard-to-Reach Populations and Snowball Sampling not in Hard-to-Reach Populations. Sociological Methodology, 41, 347-353 (2011). doi : $10.2307 / 41336926$

20. eduroam, https://www. eduroam.org/

21. [Cisco] Exams - Training and Certification, http://www.cisco.com/c/en/us/training-events/trainingcertifications/exams.html

22. Information Literacy Standards for Science and Engineering/Technology, http://www.ala.org/acrl/standards/infolitscitech

23. Richards, J.C.: Curriculum Approaches in Language Teaching: Forward, Central, and Backward Design. RELC Journal, 44, 1, 5-33 (2013). doi : $10.1177 / 0033688212473293$ 